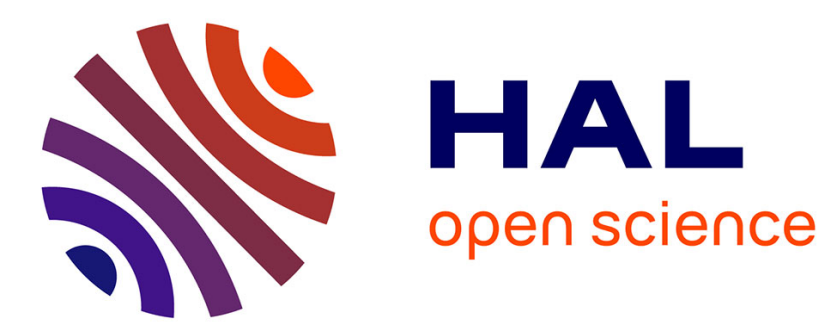

\title{
Do Science and Money Go Together? The Case of the French Biotech Industry
}

Rodolphe Durand, Olga Bruyaka, Vincent Mangematin

\section{To cite this version:}

Rodolphe Durand, Olga Bruyaka, Vincent Mangematin. Do Science and Money Go Together? The Case of the French Biotech Industry. Strategic Management Journal, 2008, 29 (12), pp.1281-1299. 10.1002/smj.707 . hal-00422650

\section{HAL Id: hal-00422650 \\ http://hal.grenoble-em.com/hal-00422650}

Submitted on 8 Oct 2009

HAL is a multi-disciplinary open access archive for the deposit and dissemination of scientific research documents, whether they are published or not. The documents may come from teaching and research institutions in France or abroad, or from public or private research centers.
L'archive ouverte pluridisciplinaire HAL, est destinée au dépôt et à la diffusion de documents scientifiques de niveau recherche, publiés ou non, émanant des établissements d'enseignement et de recherche français ou étrangers, des laboratoires publics ou privés. 


\title{
Do Science and Money Go Together? The Case of the French Biotech Industry
}

\author{
Rodolphe Durand \\ HEC school of management, Paris \\ 1 , rue de la liberation \\ 78351 Jouy en josas cedex \\ France \\ 33139677277 (phone) \\ 33139677084 (fax) \\ durand@hec.fr \\ Olga Bruyaka \\ EM Lyon \\ 29 Guy de Collonge \\ 69132 Ecully Cedex \\ France \\ bruyaka@em-lyon.com \\ Vincent Mangematin \\ Grenoble Ecole de Management \\ and \\ GAEL INRA/UPMF \\ BP $47 \mathrm{X}$ \\ 38040 Grenoble Cedex \\ France \\ Vincent@grenoble.inra.fr
}

This research was partially funded by the HEC Foundation. We thank the participants of the Unlocking biotech track at the EGOS 2005 conference (Berlin) for their comments. We are particularly indebted to Woody Powell for his review of a previous version of this paper and for suggesting its title, as well as to the organizers of the track, M. Ebers, M. Gittelman, M. Higgins, and A. Oliver. We acknowledge the valuable comments and inputs from the Strategic Management Journal's editor and reviewers. 


\title{
Do Science and Money Go Together? \\ The Case of the French Biotech Industry
}

\begin{abstract}
Developing technological applications, entering exploitation alliances, and choosing between a research- or service-focused strategic orientation are decisions that high-tech firms must manage concurrently. This paper explores systematically the contrasting effects of these strategic determinants on rent-generation and rent-appropriation using the entire population of French biotech firms (1994-2002). Findings indicate that science and money do not go unconditionally together - the direct relationship between rent-accruing resources (e.g., patents or articles) and rent appropriation varies depending on the type of resources and the strategic orientation. Moreover, the effects of strategic determinants differ for rent-generation vs. rent-appropriation: 1) technological application diversity undermines a firm's capacity to appropriate rents - in particular for research-oriented firms; 2) exploitation alliances favor rent generation but hinder rent appropriation; 3) service-oriented firms exhibit significantly better performance than research-oriented firms. Such evidence challenges the emergence in the biotechnology industry of a 'one-best' strategic trajectory, as represented by research-intensive start-ups funded by private money engaged in publishing and patenting races.
\end{abstract}

Keywords: rent generation, rent appropriation, value drivers, biotech industry 
Converting owned technology and scientific knowledge into money constitutes a great challenge for the majority of high-tech firms. These firms must strike a balance between 1) the potential benefits of technological application diversity for generating rent-accruing resources vs. lowered short term performance due to the higher costs implied by technological application diversity; 2) the positive role of exploitation alliances for rent generation and their potential negative impact on rent appropriation due to the higher leverage possessed by incumbent allies; 3) the short-term returns induced by a firm's strategic positioning as a service provider vs. more uncertain rent appropriation when positioned as a research-oriented firm. At stake lies an understudied phenomenon of strategic importance, the relationship between rent generation and rent appropriation.

Theoretically, this article addresses essential questions that have been tackled separately in prior research. First, it distinguishes rent generation from rent appropriation as two outcomes for which three crucial antecedents have contrasting expected influences: i) Past studies consider technological diversity in terms of upstream research diversity (Rosenkopf and Nerkar, 2001; Nesta and Saviotti, 2005; Sampson, 2007), but few if any address the potential diverging influence of downstream application diversity on rent generation and rent appropriation; ii) Although arguments in support of alliances' positive effect on rent generation seem robust, one might question what their consequences are on rent appropriation (Baum, Calabrese and Silverman, 2000; Alvarez and Barney, 2001; Lavie, 2006); iii) Strategic orientation has been proved to be an important moderator of rent appropriation (e.g. Durand and Coeurderoy, 2001) that, despite its relevance, seems to have lost scholars' interest in recent times.

Second, various theoretical perspectives explain rent creation at the organizational level, suggesting that rent generation derives mainly from distinctive resources (Barney, 1991; Peteraf, 
1993) or transactional or network advantages (Williamson, 1985; Gulati, Nohria and Zaheer, 2000; Afuah, 2000), and associate the presence of rent-accruing resources with rent appropriation. Yet the linkage between rent generation and rent appropriation may not be as direct and deserves further inquiry (Coff, 1999; Coff and Lee, 2003). We therefore test the possibly unique impacts of these three antecedents on both rent generation and rent appropriation, and the direct relationship itself between rent-generation and rent-appropriation.

Moreover, the vast majority of empirical research centers on biotech firms with pharmaceutical applications, but ignores the important sectors of services and agricultural and veterinary applications (e.g. Powell, White, Koput and Owen-Smith, 2005; Rothaermel and Deeds, 2006; McNamara and Baden-Fuller, 2007). In addition, observation biases restrict the studied population to the 'star scientist-IPO (Initial Public Offering)' type of companies, ignoring the wealth of influential biotech companies that do less research but offer services to more technologically oriented firms. These empirical restrictions are not without consequences for the way in which rent potential has been theoretically associated with rent appropriation.

We use an original and extensive data set of all the French biotech firms operating between 1994 and 2002 to conduct our analyses. Rent generation is measured by a firm's patents and articles, and rent appropriation by its short term profitability. First, we find that technological application diversity positively affects a service-oriented firm's rent generation potential and negatively influences a research-oriented firm's rent appropriation. Second, exploitation alliances with incumbent firms favor rent generation, but are negatively related to research-oriented firms' rent appropriation. Third, service-oriented firms exhibit a higher rent appropriation than researchoriented firms. Fourth, empirical analyses demonstrate the contrasting influence of rent generation variables on firms' rent appropriation, so that scientific articles contribute to short- 
term performance whereas patents appear detrimental in the short term.

Overall, this study emphasizes the significance of fine-grained analyses of strategic decisions: what scope for technological applications should firms retain, what are the consequences of exploitation alliances, and which strategic positioning should firms adopt? It provides evidence of the differentiated impacts of these antecedents on rent generation and rent appropriation, and of the crucial importance of distinguishing the former from the latter, since science and money do not go unconditionally together. Finally, it corrects a bias toward the idea that there is 'one-best-way' to be successful in the biotech industry (research intensive firms funded by venture capital going public), and uncovers a vast group of oft-ignored players: private firms and firms involved in agricultural and veterinary biotech sub-sectors.

\section{THEORETICAL CONTEXT AND HYPOTHESES}

Any firm's strategic mission consists of creating value and appropriating the rents that accrue to that value. Value creation entails a process of using the productive services associated with owned and controlled tangible and intangible resources (Penrose, 1959; Winter, 1995; Barney, 1991). Valuable, rare, imperfectly imitable, and non-substitutable resources establish conditions in which a firm may generate rents. In science-based industries, for example, research articles provide signals of scientific competency, the legitimacy of future products, and promises of profits (Powell et al., 2005), and thus indicate a firm’s rent generation potential.

However, high-tech firms in general, and biotech firms in particular, encounter difficulties in transforming their rent potential into profits. The case of PPL Therapeutics, which in 1996 'invented’ Dolly, the first cloned animal, is emblematic: despite this widely publicized scientific breakthrough, the company still failed. Recent findings show also a disjunction between highprofile research resources and lucrative innovations, to the extent that influential scientific papers 
are actually negatively correlated with successful innovations (Gittelman and Kogut, 2003). Rent appropriation ensues only when rent potential can be realized, and where the profits of this realization exceed the costs of deploying the necessary services (Coff, 1999; Moran and Ghoshal, 1999). Thus, recent research and anecdotal evidence both suggest that, however richly endowed with scientific capabilities, firms may not always become profitable innovators. Producing science may not automatically lead to generating cash, at least in the short run. We investigate the impacts on both rent generation and rent appropriation of the two most essential strategic factors behind biotech firms’ performance as evidenced by prior research: technological application diversity and exploitation alliances. Next, we study the direct linkage between rent generation and rent appropriation and how it may be affected by a firm’s strategic orientation.

\section{Impacts of technological application diversity and exploitation alliances}

In research-intensive industries, the tension between rent generation and rent appropriation increases as $R \& D$ costs grow, so firms often look for strategies to generate and appropriate rents through diverse technological applications and by entering markets with the same technology. In the biotech sector, most firms concentrate their technological applications in one field (e.g., animal health, human health, vegetal production, cosmetics), though some diversify into multiple fields. As an example, a firm might test new molecules, drug delivery mechanisms and vaccine methods for the veterinary market before extending them to human applications. Thus, technological application diversity, defined as the number of application fields addressed by a firm’s technological resources, provides a means for a firm to benefit from economies of scope, because it applies the same technology in different contexts or adapts that technology from one field to another. Previous studies have shown that technological diversity (commonly expressed as the diversity of a firm's patent portfolio) is an antecedent of rent generating resources 
(Sampson, 2007) and performance (Nesta and Saviotti, 2005). Although empirical research stresses the importance of a firm's technological coherence, the consequences of a firm's technological application diversity for its rent generation and rent appropriation demand further inquiry.

Four arguments combine to explain why diversity of technological application fields may be positively associated with creating rent potential. First, from an internal point of view, the valuable exploitation of rare knowledge can benefit from explorations into varied application domains (complementary effect). Biotech firms could leverage their knowledge and techniques by linking projects across biotechnology subfields and thus increase their product innovation and research outputs (Shan, Walker and Kogut, 1994). Second, feedback effects from diverse areas can contribute to discoveries in related areas. Such spillovers have a greater likelihood of assimilation by companies with diverse technological application fields than by companies that have remained more focused (Rosenkopf and Nerkar, 2001). Third, for application-diverse firms, rent potential correlates with underlying asset values (specific knowledge), but also with the field's competitive conditions and the systematic risk associated with explored activities. For example, animal and human health activities do not involve the same competition and risk conditions. Hence there exists a real-option mechanism that enables active investments and research in a specific domain to spawn different, optional values in another activity (Shane, 2001). Fourth, ecological arguments state that overly specialized firms undermine their ability to react to and survive in a changing competitive landscape, such as the biotechnology industry (Carroll, 1985; Levinthal, 1997). Overall, we posit:

H1a: Technological application diversity has a positive effect on biotech firms' rent generation potential (i.e. research outputs). 
Biotech firms explore market opportunities by diversifying their technological applications, which are research-intense and usually contain an important tacit element. When the knowledge about how to take advantage of a market opportunity is tacit in nature, decisions about how to organize the resources necessary to generate the rents associated with this opportunity can be made independently of decisions about how to appropriate those rents (Alvarez and Barney, 2004). Moreover, when a firm specializes on one key application, although it exposes itself to opportunism, its clients are better identified, and it can develop specific, unique competencies that increase its market power and negotiation position. Therefore, addressing diverse application fields, while having a positive effect on rent generation potential, may not lead to improved rent appropriation.

Accordingly, the choice between technological application specialization vs. diversity should take into account the firm's operational costs. Technological application specialization both reduces the costs of exploitation and organization and decreases communication costs (e.g., explanation, assessment, clinical tests, trials), because audiences are more uniform and concentrated - all factors that point to a lowered likelihood of rent appropriation in case of high technological application diversity. Moreover, technological application specialization generates clearer and closer market feedback than technological application diversity; in addition, it corrects itself sooner and yields more positive returns in the short term (Levinthal and March, 1993). By contrast, technological application diversity requires greater investments so that the firm can master the technological specificities and commercial needs of different markets. Whereas the capacity to transform rent potential into rent appropriation depends on information processing simplicity, technological application diversity complicates organizational rules, functioning and behavior, increasing organizational costs and deteriorating the bottom line. 
Therefore, rent appropriation and the short-term performance of technologically diverse firms should be on average poorer than that of technologically specialized companies.

H1b: Technological application diversity has a negative effect on biotech firms' rent appropriation (short-term performance).

According to dynamic capabilities theory, rent generation requires not only a bundle of resources but also mechanisms by which firms accumulate skills and competencies (Teece, Pisano and Schuen, 1997). To realize value creation, firms must accumulate, combine and exploit resources (Sirmon, Hitt and Ireland, 2007). The biotech industry is a typical case, with smaller firms combining their resources with those of incumbents to exploit existing rent potentials (Stuart, Hoang and Hybels, 1999; Rothaermel and Deeds, 2004). Empirical analyses of interfirm alliances indicate that variables such as types of alliances (Powell, Koput and Smith-Doerr, 1996), types of partners (Baum et al., 2000), alliance motivations (Gulati and Higgins, 2003), and alliance organization (Sampson, 2007) influence both firm innovative performance (Deeds and Hill, 1996; Rothaermel, 2001) and economic performance (Stuart, 2000). That is, firms that are deeply engaged in cooperation with powerful actors tend to achieve higher levels of rent generation (Stuart et al., 1999; Rothaermel and Deeds, 2004).

Exploitation alliances that focus on the " $\mathrm{D}$ " in the $\mathrm{R} \& \mathrm{D}$ process bridge the gap between rent generation and rent appropriation by uniting biotech firms with larger incumbent groups to manage the development, clinical trials, regulatory process, commercialization and distribution phases. Such alliances represent significant antecedents of innovative performance (Rothaermel and Deeds, 2004). In this sense, exploitation alliances constitute a critical dilemma for biotech firms, since they may have opposing effects on rent generating potential and rent appropriation. 
Exploitation alliances might strengthen a firm’s rent-generation potential; as strategy and organization scholars stress (Baum et al., 2000), benefits accrue to an allying organization, particularly small or resource-poor firms. For young or small firms in the biotechnology industry, strategic alliances with prominent pharmaceutical and health care organizations send powerful signals to outsiders (Stuart et al., 1999; Soh, Mahmood and Mitchell, 2004), which venture capitalists and financial markets value as indicators of the firm's ability to commercialize its scientific results (Baum and Silverman, 2004; McNamara and Baden-Fuller, 2007). Ceteris paribus, the smaller the scale and scope of the focal firm's shared resources (relative to those of its partner) the higher the proportion of relational rents appropriated by the focal firm will be (Lavie, 2006). In support of this argument, empirical studies reveal that small firms with limited resources benefit more from alliances than do their affluent established partners, even when controlling for firm age (Stuart, 2000). Moreover, a firm’s embeddedness provides a potential source of entrepreneurial opportunities and thus rent potential, because sources of innovation do not reside exclusively within firms but instead are "commonly found in the interstices between firms, universities, research laboratories, suppliers, and customers” (Powell et al., 1996). Entrepreneurial firms that can identify and exploit synergistic, value-creating opportunities with partners that own complementary resources and capabilities may obtain an advantage over those that are either unable or unwilling to do so (Sarkar, Echambadi and Harrison, 2001). Therefore, we argue

H2a: Exploitation alliances have a positive effect on biotech firms' rent generation potential (i.e., research outputs).

However, though exploitation alliances buttress rent generation potential, this is not necessarily indicative of who appropriates the generated rents. Thus, while exploitation alliances 
imply rent-creating mechanisms, we question whether they are conducive to a biotech firm's rent appropriation.

As we mentioned previously, it is not rent generation potential per se, but rather the ability to access, exchange and control resources effectively that ensures rent appropriation (Coff, 1999). However, while putting the emphasis on alliance benefits, alliance literature often ignores the possible costs associated with alliances and how they are split between the partners (Bae and Gargiulo, 2004). Bae and Gargiulo (2004) offer evidence regarding the effects of partner substitutability and alliance network structure on organizational profitability. In the U.S. telecommunications industry, they show that ties to rich and powerful organizations carry costs unless they are embedded in ties with third parties that are used to gain leverage. Gulati and Higgins (2003) report no main effects for the impact of strategic alliances between big pharmaceutical companies and small biotechnology firms on the IPO success of the latter. Morrow et al. (2007) relax Stuart et al.'s (1999) assumption about the signals alliances send to outsiders, suggesting instead that access to new resources through alliances or joint ventures do not affect investors’ expectations of biotech firms’ performance.

Small firms engaged in alliances with large and powerful partners experience rent appropriation asymmetries. Alvarez and Barney (2001: 139) argue that much of the rent created through alliances often gets appropriated by the larger partner: "While large firms are usually able to gain access to an entrepreneurial firm's new technology through an alliance, the long-term success of entrepreneurial firms can actually suffer from their alliances with large firms.” The nature of the asymmetries can increase the risk of inequitable rent appropriation, according to the larger, more established partner's greater absorptive capacity, stronger contractual routines, and 
lower dependence on the biotech firm. Dhanaraj and Parkhe (2006) similarly reason that large firms benefit from exploitation alliances because they can orchestrate the innovation network.

Large, established players also benefit from their experience and proven competencies in the downstream phases of testing, regulatory management and product distribution. In addition, large and established players - such as pharmaceutical companies - use compatible language and vocabulary that reduces the interpretation time necessary between parties willing to ally. Furthermore (unlike banks or other private fund suppliers) such established players understand the rent generating mechanisms well, and are likely to possess their own research teams, labs and other facilities that can complement the resources of smaller firms to complete research protocols. Overall, large incumbents offer distinct advantages to smaller biotech firms, but these advantages can also put them in a position to appropriate a larger portion of the returns from the alliance. Thus, we expect that rent appropriation asymmetries in exploitation alliances lead to negative consequences for a focal biotech firm's rent appropriation.

H2b: Exploitation alliances have a negative effect on biotech firms' rent appropriation (shortterm performance).

\section{From rent generation potential to rent appropriation}

Regarding the relationship between rent potential and rent appropriation, we can formulate alternative hypotheses about a direct link between the two factors. Furthermore, to refine the analysis, we need to consider more nuanced hypotheses, by including the firm's strategic orientation.

At first sight, rent generation potential (i.e., research outputs such as scientific articles and patents) is positively associated with rent appropriation, since rent generation appears to be a necessary condition for rent appropriation. Although publications in academic journals do not 
represent a firm's main objective, by increasing its visibility and fostering links with the scientific community they act as a gateway in a two-directional knowledge diffusion pathway between firms and the relevant scientific communities. In a sense, the firm enters into a "gift-giving" process with the academic community that both product and financial markets value. Similarly, patent activity signals the firm's scientific competencies to potential investors and first-rate researchers and technicians, which then triggers a virtuous circle of rent generation and appropriation (Powell et al., 2005). Publications and patents also enable firms to garner public support and build their reputations, and in a research-intense, star scientist-centered, capital leverage-oriented environment, such signals of rent potential relate favorably to effective performance. Hence,

H3a. There is a positive relationship between rent generation potential (publicized research outputs) and a biotech firm's rent appropriation (short-term performance)

However, an alternative line of reasoning recognizes that publishing and patenting are costly and time-consuming actions with uncertain commercial benefits that may even have negative effects by disseminating the firm's strategic knowledge. Biotech firms face time and resource constraints and, because of their size, often cannot separate existing and emerging businesses (O’Reilly and Trushman, 2004). Furthermore, Gittelman and Kogut (2003) convincingly question the direct relationship between influential research and successful innovation, as do brokers, venture capitalists and consulting firms, which often urge academic spin-offs to focus on emerging businesses and not spend their energy on academic productions. Neither management nor shareholders consider the time and resources spent publicizing research outputs worthwhile if they do not contribute directly to performance. Tijssen (2004) thus observes a slowdown in the propensity of firms to publish their results, even as more of them 
perform research. These arguments and recent research thus imply an alternative hypothesis:

H3b. There is a negative relationship between rent generation potential (publicized research outputs) and a biotech firm's rent appropriation (short-term performance)

Finally, to avoid a univocal view of the linkage between rent potential and rent appropriation, one needs to include a biotech firm's strategic orientation in the picture (Durand and Coeurderoy, 2001). Two broad strategic positioning exist in the biotech industry. Researchoriented biotech firms seek to develop breakthroughs and appropriate the returns from them. Rent generators (i.e., publicized research outputs) represent a marker of quality for firms that are deeply involved in research and willing to maintain their scientific competencies and networks (Stuart, Ozdemir and Ding, 2007). We can expect a direct link between rent generation and rent appropriation for these companies. In comparison, service-oriented firms do not have much to publish, because they are more deeply involved in providing day-to-day services for their clients or engineering new equipment. Their business is to fulfill the existing market need for services and equipment, and their competitive advantage need not relate to scientific inquiry. Service quality (especially when equipment is not completely reliable), shorter delivery delays, and innovative uses of e-commerce can be as strong key success criteria for these firms as research capacity can be for research-oriented firms. Therefore, firms that conduct "business as usual” and deliver relevant services may not derive profits from rent generation assets like articles and patents, but may generate more cash and greater profitability with less upfront investment costs than their research-oriented counterparts. Hence:

H4. Service-oriented firms will achieve better rent appropriation (short-term performance) than research-oriented firms.

H5. The rent generation-rent appropriation path is moderated by the firm's strategic orientation (positively for research-oriented firms). 


\section{DATA AND VARIABLES}

Most studies of the biotech industry analyze large biotech American and Canadian companies (Rothaermel, 2001; Zucker, Darby and Armstrong, 2002; Niosi, 2003; Rothaermel and Deeds, 2004; Baum and Silverman, 2004), which are designed on a similar business model. They concentrate on dedicated biotech firms involved in human therapeutic and diagnostic application and thus ignore "biotech companies involved in veterinary or agricultural biotech which draw on different scientific capabilities and operate in quite different regulatory climates” (Powell et al., 2005: 1148). Because of their linkages with star scientists, these dedicated biotech firms can develop credible research programs funded by risk money (venture capital and stock market after IPO) and file breakthrough patents.

However, to study the dynamics of an entire national biotech industry, we build a data set that includes all French firms involved in biotech. Several features emerged. First, in a non-North American context, biotech start-up business models tend to be heterogeneous in terms of their scientific involvement and their access to public stock markets (Mangematin et al., 2003). Whereas at the continent level, it may be relevant ex ante to select publicly traded humantherapeutic-centered biotech companies, at the level of a European country, this selection makes less sense because (1) the number of high-powered biotech companies is quite small, (2) there are many private companies participating in the industry that do not receive money from public investors, and (3) depending on the country, some biotech activities represent substantial portions of the national economy (e.g., agricultural biotech and animal food in France). Second, instead of scrutinizing the knowledge dispersion and trajectories through patent data analysis and scientists' careers (Owen-Smith and Powell, 2001), our interest hinges on the degree of an organization's technological application diversity in one or more domains of activity (e.g., human therapeutic, 
veterinary medicine, animal food) and the relationship between publicized research outputs and profitability at the organizational level; therefore, we must include all organizations in the field. Third, certain firms are more service than technologically oriented, and thus may generate cash from their inception, which poses a different story about how to make money in the biotech industry. Excluding such companies would create a selection bias and risk biasing the statistical tests.

Therefore, we explore our research questions using a database comprising all French biotechnological companies that participated in the industry during the nine years 1994-2002, which includes 313 firms and 1,624 observations. ${ }^{1}$ This effort represents the most extensive research ever conducted on the French biotechnological industry, and includes all firms that claim to be engaged in biotech research and that are thus classified in the census of biotech enterprises conducted regularly by the French research and technology ministry. (Basic information regarding this classification can be accessed through the French research and technology ministry Web site, http://biotech.education.fr). Starting in 1994, we update the database for each incumbent and new biotech venture.

We choose this start date because 1994 represents a turning point in Europe as the biotech industry took off on two key levels:

1. Scientific: A positive perspective toward product launches created increased enthusiasm for biotech initiatives in Europe. After years of promise, several companies became ready to launch products, especially as the European Medicinal Evaluation Agency began approving biotech products. This year also marks the point at which each of the three leading European

\footnotetext{
1 A small proportion of firms may be considered incumbents in 1994, but testing our models without these incumbents (i.e., focusing only on new ventures since 1994) does not alter our results. We therefore keep these incumbents in the data set.
} 
countries (United Kingdom, Germany and France) reached important publication thresholds, in both absolute and relative terms (Reiss, Hinze and Domingues-Lacasa, 2004).

2. Financial: Private and public funds for biotech were established in 1994, marking the beginning of a new dynamic for biotech efforts in Europe (Ernst \& Young, 1999), and making it an appropriate starting date for constituting panel data in France (Ernst \& Young, 2001).

In addition, we use additional databases, as explained subsequently, to construct the variables.

\section{Rent generation potential}

To measure rent generation potential, we considered two research outputs: articles and patents. Publication data came from the Science Citation Index (SCI) and Biotech Citation Index (CDROM BCI). Articles refers to the yearly number of scientific articles published per firm during the study period (Meyer-Krahmer and Schmoch, 1998; Zucker, Darby and Brewer, 1998) and thus represents the production of new ideas and knowledge by firms. For such articles, the SCI is an excellent source because it covers a broad range of basic and applied scientific journals and lists authors, affiliations and addresses for each publication. Similar bibliometric analyses have been used for the study of science, technology, and R\&D management by corporations (Healy, Rothman and Hock, 1986; Franklin and Johnston, 1988; Lane and Lubatkin, 1998) and to identify star scientists and university/industry linkages (Zucker et al., 1998). We downloaded all publications from the French biotech firms in the SCI database and used addresses to discard homonymous names of firms from other countries, and identify each firm's yearly article publication precisely. Patent uses data drawn from the OST/OEB database to record the number of new U.S. and Europe patents owned by a biotech firm in each year. ${ }^{2}$ (When used as

\footnotetext{
${ }^{2}$ For simplicity, we do not include citations, though all models were tested with citation as a variable. Citation is the number of citations of the biotech firm's articles each year, and the results derived from the use of this variable are identical to those in models that use article.
} 
explanatory variables in our models to test $\mathrm{H} 4$ and $\mathrm{H} 5$, article_t $t$ - and patent_t $\mathrm{t} 1$ refer to the oneyear lagged values of the logged number of articles or patents.)

\section{Rent appropriation}

Using IPOs to measure rent creation by biotechnology firms in France was not considered appropriate: the vast majority of French biotechnology firms have not gone public (Allansdottit et al., 2002)3 , and thus market value measures could not be used. As private enterprises were including in our sample, we adopted traditional firm-specific financial ratios as performance measures, and while they have been criticized in the technological firm context, they remain an acceptable choice when studying an entire population of firms. Our data were gleaned from firms' compulsory annual tax declarations, collected by the Bank of France and the French Ministry of Industry and accessible via the "Diane database." Therefore, we define performance as the return on sales for each firm averaged over a two-year window.

\section{Independent variables}

For the technological application diversity and exploitation alliance variables, we collected information from all the available secondary sources, including firm's web sites and a database developed by the French professional association (http://www.francebiotech.com). We also gathered information from the business press, from sites specializing in economic information (http://siren.societes.org and http://boursorama.com), and sites focused on the medical and pharmaceutical industries (http://pharmaceutiques.com, http://chemistry.firmafrance.com, http://informagen.com, http://main.biozak.com).

\footnotetext{
${ }^{3}$ Most French biotech firms do not meet the requirements of financial markets to go public, such as the recent failed introduction on the American stock market (9/7/2005) of the French company IDM (Immuno-Designed Molecules).
} 
As derived from these sources, technological application diversity consists of the number of application domains in which the firm is involved or applies its technological resources in each year. Our definition of technological application diversity is similar to that used by Shan et al. (1994), by the Organization of Economic Cooperation and Development (OECD) to report biotechnology statistics (van Beuzekom and Arundel, 2006), and by the French biotech association. It distinguishes nine technological application domains: equipment for research, animal health, human food, vegetal production, human health, cosmetics, animal food, environment, and other. Therefore, technological application diversity values range theoretically from 1 to 9, with larger (smaller) values indicating greater diversification (specialization) by the firm.

Exploitation alliance is a dichotomous variable that indicates whether the firm has developed an exploitation alliance with at least one of the ten biggest companies in Europe in its activity domain (e.g., pharmaceutical, veterinary, agro-food). We gathered information about alliances involving biotech firms and major players and coded the variable as 1 when an alliance exploited the biotech’s firm resources (clinical tests, commercialization, promotion, distribution) and 0 otherwise. We also tested the total number of exploitation alliances (logged) and the relative number of exploitation alliances (relative to regional rivals), but the results do not improve compared with those obtained using the simple binary variable.

We used two binary variables to characterize a biotech firm's strategic orientation: service orientation (e.g., in vivo and in vitro tests, pre-clinical and clinical tests, transgenic models, monoclonal antibodies, consulting activity) and research orientation (e.g., producing innovation related to new drugs and production processes). To measure this variable, we relied on the secondary data sources and kept it stable over time, because some observation points were 
missing. (We acknowledge a liability of this variable; namely, we assume firms do not change their business orientation during the years of observation, though our knowledge of the industry and interviews indicate such a strategic switch is unlikely.) Eight percent of the firms observed pursued both strategies simultaneously, but excluding or including these observations in the models did not change the structure of the results.

\section{Controls}

We included classical control variables at the firm level. Past performance controls for the effect of the lagged return on sales from firms' current rent generation and appropriation. The debtequity ratio represents the amount of a firm's debt divided by its equity, which varies depending on the firm's strategy because firms pursuing a research orientation need to invest more money in their discoveries and leverage more debt than service-oriented companies. Firm size, measured as the logged number of employees, related positively to both research outputs and performance (Rothaermel and Deeds, 2004). We also controlled for whether a firm's stocks were publicly traded (Public equal to 1) or not (equal to 0). Because the risk profile of investors and entrepreneurs depends on a firm's governance type, we coded this variable as 1 for "unlimited liability," which is more risky for entrepreneurs, clearly distinguishes between management and ownership, and is the dominant form for listed companies and venture capitalists, and 0 for other types of governance.

We also controlled for the origin of firms according to three distinct origins: spin-offs from existing companies or universities; subsidiaries of existing companies in which the parent companies maintained equity investments; and independent companies launched by groups of independent owners. Spin-offs serve as the reference category for the origin variable. Finally, we controlled for accumulated company experience in the industry and for prior creation using two 
variables: experience, which captures the effect of age from 1994 onward and equals the logged number of years in the data set, and censure-left, which equals 1 if the company existed before 1994 and 0 otherwise.

Among the controls external to the firm, we deployed two factors in the final models because of their significant influence. First, a firm's rent generation and rent appropriation can be influenced by its location and, in particular, the dynamism of its geographical cluster. To measure this factor, for each of the 22 French regions, we divided the annual number of articles published by authors in a given region (whether from private or public entities) that included another author from an international organization by the total number of published articles in the biotechnology sector for that region in the given year. Thus, international exposure measures the degree of international co-publication, aggregated to the regional level. Co-publications signal effective collaborations among institutions and indicate the regional organizations' capacity to meet international research progress. We posit that international exposure relates positively to the rent generation potential variables (article and patent). Second, density measured the yearly logged number of biotech companies operating in the French biotech industry and thus captured the effect of local competition.

\section{Methods}

The data used in this research are longitudinal and follow a set of companies over time. Overall, our panel sample comprised 1,624 observations relating to 313 firms over nine years (19942002). All the independent and control variables are lagged one year. We note that panel data offer several advantages compared with traditional cross-sectional data, such that they enable us to control for lagged effects, enhancing the efficiency of econometric models. 
For rent generation potential (count variables of article and patent), we used randomeffects negative binomial regressions, which allowed the mean and variance of the Poisson process to vary by introducing individual unobserved disturbance. Because individuals may appear repeatedly in our data set, we adjusted the standard errors for clustering effects.

To test the hypotheses pertaining to rent appropriation, we used generalized least squares (GLS) regression analysis, which produced more efficient estimates than a general linear regression model (Greene, 2005). In addition, GLS estimates were corrected for autocorrelation and cross-section heteroskedasticity while estimating the weighted averages of within- and between-firm effects. The presence of both unobserved individual effects uncorrelated with regressors (Hausman test) and within-cluster error misspecifications (where a firm is present over several years) prompted us to use random-effects models with robust standard errors.

\section{RESULTS}

Table 1 reports the descriptive statistics for the variables. By its construction, the correlation coefficient between two control variables, experience and censure-left, is very high. After checking the individual effects of these variables separately, and in absence of differences in the results, we present the models with the two variables jointly.

\section{> > Insert Table 1 about here $<<$}

In Table 2, models 1-4 indicate the results related to the two dependent variables that capture rent generation. Several control variables have convergent effects on these variables; for example, prior performance relates negatively to both article and patent, whereas size and international exposure are positively associated with both rent generation indicators. Status as an independent company relates positively to patent, but not significantly to article, whereas the density of competitors stimulates article, but does not affect patent. A contrasting result emerges 
from experience and censure-left, in that both work against the production of patents but influence the article indicator positively.

These results support the well-known story about building value-accruing assets. Research outputs are costly to achieve, and bigger ventures that belong to research-intensive locations connected with international teams perform better. Age and experience have favorable effects on article production, while patenting companies tend to be younger and more independent.

When we include technological application diversity and exploitation alliance into the baseline models 1 and 3, the Wald Chi ${ }^{2}$ improves significantly (models 2 and 4). In H1a, we argue that technological application diversity should improve a biotech firm's rent generation potential, but though positive, the coefficient for technological application diversity is not significant when added by itself to the baseline models (not presented) or in conjunction with exploitation alliance (models 2 and 4). Therefore, H1a is not supported.

In H2a, we posit a positive impact of exploitation alliances on a firm's biotech rent generation potential. When included by itself in the baseline models, or in conjunction with technological application diversity in models 2 and 4, the coefficient of exploitation alliance is both positive and significant at the 1\% level, in support of H2a.

Models 5-9 deal with rent appropriation, and the effects of the control variables appear consistent across them. Past performance relates positively to current performance, as do age (censure-left) and experience. The coefficient denoting strong connections with a larger company (subsidiary) is also positive, but is only marginally significant. However, the burden of debt (debt-equity), degree of regional competition (density), and international exposure tend to reduce performance.

Model 6 includes the two independent variables for testing H1b and H2b. The coefficients 
for technological application diversity and exploitation alliance are both negative and significant $(p<.01)$, indicating that they have negative effects on a biotech firm's rent appropriation, in support of H1b and H2b. These results indicate that biotech firms face a major dilemma, at least as far as exploitation alliances are concerned: while exploitation alliances strengthen their rent generation potential (i.e., visible research outputs), they weaken firms' capacity to extract and benefit from this rent potential.

Model 7 adds the lagged rent generation variables (article_t-1 and patent_t-1) to test H3a and H3b, which hypothesize either a positive or negative effect of rent generation potential on performance. Results from model 7 do not provide conclusive support for either hypothesis, because the article_t $t$ coefficient is positive and significant, whereas the patent_t 1 coefficient is negative and significant.

In H4, we argue that service-oriented firms achieve better rent appropriation than research-oriented firms, and models 8 and 9 introduce both strategic orientations. As we expected, research orientation has a negative and significant influence (model 8), whereas service orientation bolsters performance (model 9). Thus, we find support for H4: developing a serviceoriented strategy positively influences short-term profitability, whereas focusing on research for breakthrough innovations relates negatively to firm profitability.

$$
>\text { Insert Table } 2 \text { about here }<<
$$

To investigate the impact of strategic orientation further and test H5, we ran models 2, 4, and 7 for each strategic subgroup, that is, research-oriented firms (models 10-12) and serviceoriented firms (models 13-15), and thus refine our prior interpretations. For example, among research-oriented firms, size has a greater influence in terms of generating patents than articles, but the influence of density is more significant for articles than for patents. In both cases (models 
10 and 11), the structure of results is similar to that of models 2 and 4, such that technological application diversity is insignificant and exploitation alliance significantly and positively influences rent generation potential. The findings in model 12 also converge with those in model 7, in exhibiting the contrasting effect of the positive influence of the number of past articles but the negative impact of the number of patents.

Similarly, models 13-15 offer some nuanced results for service-oriented companies. For example, the effects of the debt-equity ratio and subsidiary are particularly significant for patents. In addition, technological application diversity appears as positively and significantly related to rent generation potential (models 13 and 14), in support of $\mathrm{H} 1 \mathrm{a}$, although at the general level this effect is not sustained (models 2 and 4). Therefore, among service-oriented biotech firms, those that address several application fields appear more likely to publish or patent their findings, but when we group them with research-intensive firms, this effect disappears because the average effort devoted to research and resulting productivity is substantially lower for the former (models 10 and 11). Moreover, as model 13 confirms, past rent generation potential does not transfer into actual performance in the case of service-oriented firms: article_t-1 and patent_t-1 reveal no significant effects.

From these results, we can conclude support for H5, because the impact of rent generation potential on performance is greater and significant for research-oriented biotech firms than for service-oriented firms.

\section{>>Insert Table 3 about here $<<$}

\section{Robustness checks}

We next conducted a series of robustness checks. First, we tested some other control effects in the models, but found they contributed little to the analysis. In particular, additional regional 
indicators that measured cluster effects and agglomerated economies proved insignificant. ${ }^{4}$ We interacted the logged number of articles and patents at t-1 and t-3 with the regional advantage indicators to determine whether firms captured regional spillovers differently (Almeida and Kogut, 1999). For example, more prolific researching and patenting companies might concentrate on spillover benefits. However, these results were not significant either, which implies little (if any) regional advantage impact on French biotech firms' rent generation potential.

Second, alternative measures of exploitation alliances (e.g., logged number of exploitation alliances, relative number of exploitation alliance compared with regional rivals) yielded the same results as those presented for both rent generation and rent appropriation indicators. However, we also tested the differential effects of alliance types, using the proportion of exploitation alliances relative to the total number of alliances, and found insignificant results in both linear and quadratic relationships. When we used the logged number of upstream (with research labs and other suppliers) and horizontal (with other small biotechs, or with bigger firms for efforts other than commercialization and distribution) alliances instead, we only found a marginally significant negative coefficient $(p<.08)$ on the firm’s performance, which implies that $\mathrm{H} 2 \mathrm{~b}$ might be extended to more general types of alliances.

Third, we tested some moderating effects on technological application diversity by interacting exploitation alliances with technological application diversity and testing the impact on rent generation potential (patent and article) and firm performance. For patent and article, we found no significant results, but for performance, we found a positive interaction coefficient,

\footnotetext{
${ }^{4}$ None of the following indicators achieve significant results: regional funding, or the proportion of state and regional funding devoted to biotech research (targeted at universities and companies within a region) relative to the overall state and regional investments for all industries in this region; $P h D$ density, an index of the number of Ph.D.s in biosciences in a given region relative to the worst endowed region; and absolute regional focus, the logged amount of private investment in biotech $\mathrm{R} \& \mathrm{D}$ (unlike regional focus, which is a proportion).
} 
marginally significant (at 10\%) for research-oriented firms but nonsignificant over the entire population. That is, research-oriented biotech firms may mitigate the negative influence of technological application diversity on performance by developing some exploitation alliances with incumbents, whose direct and main effects remain negative and significant. Furthermore, as some studies had suggested that after the exploration phase, biotech firms tend to concentrate more on specific research domains, we investigated whether experience in the industry might moderate the impact of technological application diversity on performance. None of the interaction coefficients between experience and technological application diversity proved significant (on patent, article, and performance).

Fourth, we used a three-year lag to validate the results of model 7, but the pattern of results remained unchanged. Technological application diversity_t-3 was significantly and negatively associated with performance, whereas article_t-3 increased a firm's rent appropriation. The coefficients of exploitation alliance_t-3 and patent_t-3, though still revealing the anticipated negative influence, became insignificant.

Fifth, we studied alternative groupings of firms. Specifically, we used the debt-equity ratio as a surrogate for a research orientation, because firms with more debt were more likely to be research oriented. The results confirmed our findings from models 10-15. We also investigated whether governance or public status lead to contrasting results but found no further interesting results.

\section{DISCUSSION}

This study tests how factors such as technological application diversity, exploitation alliances, and strategic orientation differ in their influence on high-tech firm's rent generation and rent 
appropriation. We conduct our study in a French context during the first decade of national biotechnology industry development (1994-2002) and find that the factors that enhance rent generation potential do not automatically enhance rent appropriation. In other words, for biotechnology firms, science and money do not necessary go hand in hand.

In this section, we review the contrasted hypotheses presented in the theoretical section and discuss the reported results, as well as possible avenues for further research. The first critical issue that biotech firms consider in their development is the number of their technological applications, as captured by our technological application diversity variable. Specifically, we expected this factor to favor firms' rent generators (articles and patents) but undermine their rent appropriation. On the one hand, our results confirm the negative impact of technological application diversity on short-term profitability, especially among research-oriented firms; so the arguments which caution that technological application diversity can increase intraorganizational, test, and commercialization costs and complicate organizational rules and behavior appear valid. The short-term performance stemming from the rent generating resources of firms with a diverse set of technological applications is lower than that of research-focused companies. On the other hand, we cannot confirm an overall positive effect of technological application diversity on rent generation potential (patents and articles), though we observe the significant expected effect among service-oriented firms, at $p<.05$ for article and $p<.10$ for patent. There is therefore some evidence that service-oriented companies who enter several fields can develop and defend their rent generating resources better than their peers who cater to clients from a single application field. However, when we consider all firms together, the positive effect of technological application diversity on rent generation potential vanishes. 
These results should be interpreted with care, because our measure, which is similar to the measures used by Shan et al. (1994), the official statistics for the OECD, and national biotech associations, covers the number of technological applications a biotech firm addresses. However, technological application diversity differs from a measure of technological diversity, such as that used by Sampson (2007), which accounts for the number of patent classes and their relatedness. Therefore, we acknowledge the difference between contemplating diverse technological applications (downstream diversity) and developing a coherent family of patents to protect future products (upstream technological diversity). Further research should include different measures of diversity (technological diversity, technological application diversity, and others) in the same study to determine their potentially unique effects on rent generation and rent appropriation by high-tech firms.

Which alliance strategy to adopt constitutes a second critical dilemma for biotech firms, because exploitation alliances have opposite effects on rent generating potential and rent appropriation. Our results reveal that, while small biotech firms benefit from their alliances with established partners in terms of enhanced rent potential, they often cannot protect or properly appropriate those created rents. This result supports findings reported in previous studies by Bae and Gargiulo (2004), Gulati and Higgins (2003), and Morrow et al. (2007), which question the positive effect of alliances with established partners on small firm's profitability, at least in the short term. How can biotech firms engaged in alliances appropriate their rents properly? Although this question lies outside of the scope of our paper, current research has started elaborating some possible solutions, ranging from radical (i.e., going it alone, which may not be a possibility for a biotech firm, which will often have only limited resources) to challenging (i.e., maintaining the ability to be inventive and constantly producing a stream of new technologies) 
(Alvarez and Barney, 2001). Because we believed this issue worth exploring, we ran additional tests of the interaction effect between technological application diversity and rent appropriation and found that research-oriented biotech firms that diversified their technology in several application fields improved their rent appropriations when engaged in exploitation alliances. However, this interaction effect was only supported for the research-oriented subpopulation of biotech firms. Therefore, further research should test the interaction effect with technological application diversity more precisely and define its role in the rent generation/appropriation efforts of entrepreneurial firms.

A third dilemma pertains to the relationship between rent potential and rent appropriation. Our results do not provide specific support for either a positive or a negative relationship between research output and short-term profitability. Although we uncover a positive relation between published scientific articles and biotech firms' short-term profitability (with one to three-year lag), patents have a significant negative effect on rent appropriation (which becomes insignificant with a three-year lag). In addition, these results apply to research-oriented but not to serviceoriented companies. Our results thus echo growing evidence (Gittelman and Kogut 2003) that the linkages between scientific production (patents) and a firm's ability to generate cash are not as strong as previously believed. Firms must strike a balance between publication and patenting, even though American and European rules regarding these priorities are not completely alike. Moreover, as patenting assumes novelty, and it is impossible to patent published results (Arundel, 2001; Somaya, 2003), a firm might choose to publish research results to prevent competitors from patenting (Lerner, 1994). Patents are a costly means of intellectual property protection that require substantial financial outlays from the deposition stage up to the delivery of the patent and its validation in different countries, depending on the application specification, and these 
expenditures have to be committed before the economic value of the patent becomes certain. A patenting biotech firm must make huge investments in rent potential (up to $€ 41,000$ for a European patent, not including maintenance costs) without any guarantee of future rent appropriation (Deberdt, 2005). Thus, the negative relation between patents and profitability in the short-term might not seem surprising. We also note that traditional research into the effects of patents on profitability use longer observation windows and longer time lags. In this sense, the selected disclosure of research outputs (articles and patents) represents a strategic firm decision that signals specific capabilities and attracts capital (monetary and social) for implementing the associated strategy.

Such evidence also may challenge the emergence of the new 'one-best' strategic trajectory in the biotech industry, as represented by research-intensive start-ups funded by private money engaged in publishing and patenting races. In fact, such firms often cannot capitalize on their scientific breakthrough: both PPL Therapeutics ('Dolly's' inventor) and Genset (which developed large research programs to identify genes involved in important pathologies like obesity or cancer) failed, despite exhibiting all the characteristics of successful companies (e.g., cutting-edge scientific results, patents, publications, reputed scientists on their scientific advisory board, venture capital, alliances with big pharma companies). Empirical work in the United States and Canada, which tends to use listed companies that are still in their initial, flamboyant strategic stage, may have created a biased conceptualization of how money can be made in emerging sectors. Our analysis, which uses data about the entire French biotech industry, shows that service companies that supply life-science, research-intensive companies make money in a very traditional way: They sell services and products successfully, without being at the cutting edge of science. This strategic model portrays biotech firms as more traditional market actors that 
offer life-science industries diagnostic kits and services. Even if they are involved in high-tech, science-based industries, they still run their business as usual by filling market gaps, targeting emerging needs, and providing specialized services for research labs and industries. For these firms, secrecy is often enough to guarantee benefits from their innovation, as the services they offer generally reveal minimal information about techniques. In addition, because of their smaller size, they are unlikely to be able to support the costs of a trial of an imitation product, and thus they patent little, at least less than their research-oriented counterparts. Instead, service-oriented firms generate cash from their day-to-day activities and function as a sort of specialized "cornershop” for life scientists. But (as Tesco or Carrefour remind us) corner-shops can be profitable and grow. This sub-sector of the biotech industry — the immersed, unseen section of the iceberg benefits from better short-term rent appropriation than does the visible, widely recognized peak.

Naturally, the ensuing question centers on how to resolve these controversies and formulate guidance for biotech firms' research and alliance strategies: our study offers a partial answer. We hypothesize that biotech firms' strategic orientation (research or service oriented) plays a role in how the firm balances its rent creation/rent appropriation processes. Moreover, our findings suggest that technological application diversity and alliance strategies have different, though predictable, effects depending on strategic orientation which offer some important implications for biotech firms. First, depending on their goals, firms should recognize that the impact of rent generation potential on performance is greater for research-oriented than for service-oriented firms. Second, service-oriented biotech firms should note that addressing a more diverse set of application fields will likely mean they publish or patent more findings than their peers (though this effect does not contribute directly to their profitability and fades away at the whole-industry level). Third, research-oriented biotech firms with diversified technological 
applications can partially compensate for their lower average performance by engaging in exploitation alliances with large incumbents.

This series of results is not free from particularities and limitations. First, the national context may prevent the generalization of our findings to other countries, especially because the French context possesses some specific characteristics (as discussed in the Data section - e.g., few biotech firms going public, importance of agriculture in the national economy). Second, the biotech industry possesses idiosyncratic characteristics (e.g., level of uncertainty, duration of research projects, symbiotic interorganizational links) that may represent another hindrance to generalizations to other research-intensive and high-tech industries. Third, our empirical setting consists of all French biotech firms; that is, we do not select firms ex ante according to sector, governance or capability characteristics. Despite the empirical interest of this approach, it also means that we lack access to finer-grained information about alliances, research strategies and performance. Fourth, although some of the measures (e.g., technology application diversity) are coarser than we would have liked (e.g., technology application diversity), that coarseness gives a conservative bias to the analysis, because such measures deflate variance and the likelihood of obtaining significant results (Hunter and Schmidt, 1990).

Limitations aside, this study contributes to ongoing research into the balance of rent generation and rent appropriation by highlighting three controversies that academic research in strategy and entrepreneurship should continue to investigate: (1) the impact of entering several downstream technological application fields varies depending on the strategic orientation of firms; (2) exploitation alliances with established partners enhance rent generation potential but negatively affect biotech firms' short-term profitability; and (3) service-oriented firms better appropriate rents than do research-oriented firms, even though the impact of rent generation 
potential on profitability is greater for the latter. Further research should consider whether these findings are industry- and country- specific, as well as if more traditional effects on performance might be found using a longer window of observation and longer time lags. 


\section{TABLES}

\section{Table 1. Descriptive statistics}

\begin{tabular}{|c|c|c|c|c|c|c|c|c|c|c|c|c|c|c|c|c|c|c|c|c|}
\hline & & Article & Patent & $\begin{array}{l}\text { Perfor- } \\
\text { mance }\end{array}$ & 1 & 2 & 3 & 4 & 5 & 6 & 7 & 8 & 9 & 10 & 11 & 12 & 13 & 14 & 15 & 16 \\
\hline & Mean & 5.24 & 0.62 & -1.24 & -0.93 & 3.11 & 2.79 & 0.16 & 0.66 & 0.24 & 0.63 & 2.15 & 0.22 & 0.82 & 0.23 & 2.35 & 0.29 & 0.64 & 0.27 & 0.60 \\
\hline & s.d. & 15.50 & 1.42 & 5.52 & 4.55 & 2.71 & 1.45 & 0.37 & 0.47 & 0.42 & 0.48 & 0.53 & 0.42 & 0.91 & 0.50 & 0.85 & 0.37 & 1.44 & 0.58 & 0.49 \\
\hline 2 & Debt-equity & 0.00 & 0.02 & -0.06 & -0.02 & & & & & & & & & & & & & & & \\
\hline 3 & Size & 0.26 & 0.22 & -0.03 & -0.03 & 0.11 & & & & & & & & & & & & & & \\
\hline 4 & Public & 0.06 & 0.08 & -0.02 & -0.02 & 0.04 & 0.09 & & & & & & & & & & & & & \\
\hline 5 & Governance & 0.04 & 0.10 & -0.03 & -0.03 & 0.06 & 0.16 & 0.15 & & & & & & & & & & & & \\
\hline 6 & Subsidiary & -0.04 & -0.06 & 0.10 & 0.08 & 0.03 & 0.22 & 0.08 & -0.04 & & & & & & & & & & & \\
\hline 7 & Independent & 0.01 & 0.08 & -0.07 & -0.05 & -0.02 & -0.15 & -0.02 & 0.04 & -0.73 & & & & & & & & & & \\
\hline 8 & Density & 0.05 & 0.03 & -0.12 & -0.10 & 0.03 & 0.03 & 0.02 & -0.02 & -0.01 & -0.02 & & & & & & & & & \\
\hline 9 & $\begin{array}{l}\text { International } \\
\text { exposure }\end{array}$ & 0.21 & 0.46 & -0.20 & -0.14 & 0.02 & 0.26 & 0.06 & 0.11 & -0.10 & 0.07 & 0.07 & & & & & & & & \\
\hline 10 & Experience & -0.11 & -0.07 & -0.08 & -0.07 & 0.12 & -0.04 & -0.06 & -0.15 & 0.05 & 0.00 & 0.29 & -0.02 & & & & & & & \\
\hline 11 & Censure-left & 0.11 & 0.05 & 0.11 & 0.11 & -0.10 & 0.10 & 0.08 & 0.17 & -0.02 & 0.00 & -0.25 & 0.02 & -0.96 & & & & & & \\
\hline 12 & $\begin{array}{l}\text { Technological } \\
\text { application } \\
\text { diversity }\end{array}$ & 0.10 & 0.05 & -0.08 & -0.06 & -0.05 & 0.11 & -0.09 & 0.05 & 0.03 & -0.01 & -0.03 & 0.02 & 0.01 & 0.00 & & & & & \\
\hline 13 & $\begin{array}{l}\text { Exploitation } \\
\text { Alliance }\end{array}$ & 0.18 & 0.13 & -0.15 & -0.13 & -0.02 & -0.01 & 0.09 & 0.00 & -0.11 & 0.03 & 0.13 & 0.11 & 0.03 & -0.03 & -0.03 & & & & \\
\hline 14 & Article_t-1 & 0.18 & 0.08 & 0.05 & 0.03 & 0.08 & 0.16 & 0.01 & 0.06 & -0.02 & 0.01 & 0.07 & 0.14 & -0.13 & 0.15 & 0.01 & 0.05 & & & \\
\hline 15 & Patent_t-1 & 0.32 & 0.47 & -0.17 & -0.11 & 0.02 & 0.31 & 0.04 & 0.11 & -0.08 & 0.11 & 0.06 & 0.53 & -0.10 & 0.12 & 0.07 & 0.14 & 0.14 & & \\
\hline 16 & $\begin{array}{l}\text { Research } \\
\text { orientation }\end{array}$ & 0.12 & 0.17 & -0.11 & -0.10 & 0.02 & 0.12 & 0.06 & 0.02 & 0.06 & -0.07 & 0.02 & 0.21 & -0.01 & 0.00 & 0.15 & -0.01 & 0.05 & 0.20 & \\
\hline 17 & $\begin{array}{l}\text { Service } \\
\text { orientation }\end{array}$ & -0.08 & -0.13 & 0.11 & 0.09 & -0.03 & -0.08 & -0.03 & 0.06 & -0.12 & 0.09 & 0.01 & -0.12 & -0.03 & 0.03 & -0.15 & 0.01 & 0.00 & -0.15 & -0.86 \\
\hline
\end{tabular}


Table 2. Random-effects models on rent generation and rent appropriation

\begin{tabular}{|c|c|c|c|c|c|c|c|c|c|}
\hline & Model 1 & Model 2 & Model 3 & Model 4 & Model 5 & Model 6 & Model 7 & Model 8 & Model 9 \\
\hline & \multicolumn{4}{|c|}{ Rent Generation } & \multicolumn{5}{|c|}{ Rent Appropriation } \\
\hline & \multicolumn{4}{|c|}{ Random effects negative binomial regression } & \multicolumn{5}{|c|}{ Random effect GLS regression } \\
\hline Dep. Variable & \multicolumn{2}{|c|}{ Article } & \multicolumn{2}{|c|}{ Patent } & \multicolumn{5}{|c|}{ Performance } \\
\hline Constant & $\begin{array}{l}-.270 \\
(.191) \\
\end{array}$ & $\begin{array}{l}. .426^{*} \\
(.223)\end{array}$ & $\begin{array}{l}1.13^{* *} \\
(.144)\end{array}$ & $\begin{array}{l}1.02^{* *} \\
(.164)\end{array}$ & $\begin{array}{c}-3.29 * * * \\
(.941) \\
\end{array}$ & $\begin{array}{l}-1.35 \\
(.976)\end{array}$ & $\begin{array}{l}-.921 \\
(1.16)\end{array}$ & $\begin{array}{l}-1.07 \\
(1.00) \\
\end{array}$ & $\begin{array}{l}-1.85 \\
(1.02) \\
\end{array}$ \\
\hline Prior_Perf & $\begin{array}{c}.014^{* * *} \\
(.004) \\
\end{array}$ & $\begin{array}{c}-.013 * * * \\
(.004)\end{array}$ & $\begin{array}{c}-.016^{* * *} \\
(.004)\end{array}$ & $\begin{array}{c}-.016^{* * *} \\
(.004)\end{array}$ & $\begin{array}{c}.392 * * * \\
(.032)\end{array}$ & $\begin{array}{c}.384 * * * \\
(.032)\end{array}$ & $\begin{array}{c}.408^{* * *} \\
(.030)\end{array}$ & $\begin{array}{l}.375^{* * *} \\
(.032)\end{array}$ & $\begin{array}{l}.376^{* * *} \\
(.032)\end{array}$ \\
\hline Debt-equity & $\begin{array}{l}-.000 \\
(.000)\end{array}$ & $\begin{array}{l}-.000 \\
(.000)\end{array}$ & $\begin{array}{l}.000 \\
(.000)\end{array}$ & $\begin{array}{l}.000 \\
(.000)\end{array}$ & $\begin{array}{l}-.001^{+} \\
(.000)\end{array}$ & $\begin{array}{l}-.001^{*} \\
(.000)\end{array}$ & $\begin{array}{c}-.001 * * \\
(.000)\end{array}$ & $\begin{array}{l}-.001^{+} \\
(.000)\end{array}$ & $\begin{array}{l}-. .001 * \\
(.000)\end{array}$ \\
\hline Size & $\begin{array}{l}.058^{*} \\
(.029)\end{array}$ & $\begin{array}{l}.053^{+} \\
(.029)\end{array}$ & $\begin{array}{l}.109 * * * \\
(.021)\end{array}$ & $\begin{array}{c}.104^{* * *} \\
(.021)\end{array}$ & $\begin{array}{c}.054 \\
(.128)\end{array}$ & $\begin{array}{c}.048 \\
(.128)\end{array}$ & $\begin{array}{c}.034 \\
(.130)\end{array}$ & $\begin{array}{c}.068 \\
(.125)\end{array}$ & $\begin{array}{c}.059 \\
(.125)\end{array}$ \\
\hline Public & $\begin{array}{l}.021 \\
(.089) \\
\end{array}$ & $\begin{array}{l}.008 \\
(.089) \\
\end{array}$ & $\begin{array}{l}.093 \\
(.070) \\
\end{array}$ & $\begin{array}{l}.092 \\
(.070) \\
\end{array}$ & $\begin{array}{l}-.732^{+} \\
(.128)\end{array}$ & $\begin{array}{l}-.476 \\
(.414) \\
\end{array}$ & $\begin{array}{l}-.248 \\
(.431)\end{array}$ & $\begin{array}{l}-.452 \\
(.422)\end{array}$ & $\begin{array}{l}-.475 \\
(.421)\end{array}$ \\
\hline Governance & $\begin{array}{c}.059 \\
(.069)\end{array}$ & $\begin{array}{c}.061 \\
(.069)\end{array}$ & $\begin{array}{l}.042 \\
(.053)\end{array}$ & $\begin{array}{l}.043 \\
(.054)\end{array}$ & $\begin{array}{l}-.498 \\
(.336)\end{array}$ & $\begin{array}{l}-.475 \\
(.414)\end{array}$ & $\begin{array}{l}-.198 \\
(.335)\end{array}$ & $\begin{array}{l}-.328 \\
(.323)\end{array}$ & $\begin{array}{l}-.375 \\
(.322)\end{array}$ \\
\hline Subsidiary & $\begin{array}{l}-.072 \\
(.147)\end{array}$ & $\begin{array}{l}-.054 \\
(.147)\end{array}$ & $\begin{array}{l}.080 \\
(.104)\end{array}$ & $\begin{array}{l}.103 \\
(.106)\end{array}$ & $\begin{array}{l}1.37^{*} \\
(.616)\end{array}$ & $\begin{array}{l}1.02^{+} \\
(.593)\end{array}$ & $\begin{array}{l}.890 \\
(.609)\end{array}$ & $\begin{array}{l}1.00^{+} \\
(.604)\end{array}$ & $\begin{array}{l}1.09^{+} \\
(.603)\end{array}$ \\
\hline Independent & $\begin{array}{c}.020 \\
(.124) \\
\end{array}$ & $\begin{array}{c}.018 \\
(.124) \\
\end{array}$ & $\begin{array}{l}.228^{* *} \\
(.087) \\
\end{array}$ & $\begin{array}{l}.236^{* *} \\
(.088) \\
\end{array}$ & $\begin{array}{c}.382 \\
(.518) \\
\end{array}$ & $\begin{array}{c}.111 \\
(.498) \\
\end{array}$ & $\begin{array}{c}.092 \\
(.518) \\
\end{array}$ & $\begin{array}{c}.050 \\
(.510) \\
\end{array}$ & $\begin{array}{c}.090 \\
(.508) \\
\end{array}$ \\
\hline Density & $\begin{array}{l}.137^{* *} \\
(.050) \\
\end{array}$ & $\begin{array}{l}.121^{*} \\
(.050) \\
\end{array}$ & $\begin{array}{c}.002 \\
(.042) \\
\end{array}$ & $\begin{array}{c}.005 \\
(.042) \\
\end{array}$ & $\begin{array}{c}-.656 * * \\
(.276)\end{array}$ & $\begin{array}{l}-.558^{*} \\
(.258) \\
\end{array}$ & $\begin{array}{c}-.600^{* *} \\
(.250)\end{array}$ & $\begin{array}{l}-.552^{*} \\
(.258) \\
\end{array}$ & $\begin{array}{l}-.566^{*} \\
(.259) \\
\end{array}$ \\
\hline $\begin{array}{l}\text { International } \\
\text { exposure }\end{array}$ & $\begin{array}{c}.230^{* * *} \\
(.066)\end{array}$ & $\begin{array}{c}.228^{* * *} \\
(.066)\end{array}$ & $\begin{array}{c}.313^{* * *} \\
(.058)\end{array}$ & $\begin{array}{c}.296^{* * *} \\
(.058)\end{array}$ & $\begin{array}{c}-1.57 * * * \\
(.383)\end{array}$ & $\begin{array}{c}-1.24 * * * \\
(.360)\end{array}$ & $\begin{array}{c}-1.18^{* * *} \\
(.374)\end{array}$ & $\begin{array}{c}-1.14 * * * \\
(.364)\end{array}$ & $\begin{array}{c}-1.17 * * * \\
(.362)\end{array}$ \\
\hline Experience & $\begin{array}{c}.446^{* * *} \\
(.092)\end{array}$ & $\begin{array}{c}.416^{* * *} \\
(.092)\end{array}$ & $\begin{array}{c}-.259 * * * \\
(.070)\end{array}$ & $\begin{array}{c}-.277 * * * \\
(.070)\end{array}$ & $\begin{array}{c}1.80 * * * \\
(.461)\end{array}$ & $\begin{array}{c}1.52 * * * \\
(.434)\end{array}$ & $\begin{array}{l}1.47 * * \\
(.584)\end{array}$ & $\begin{array}{c}1.46^{* * *} \\
(.441)\end{array}$ & $\begin{array}{c}1.48^{* * *} \\
(.440)\end{array}$ \\
\hline Censure-left & $\begin{array}{c}.821 * * * \\
(.160)\end{array}$ & $\begin{array}{c}.783^{* * *} \\
(.160)\end{array}$ & $\begin{array}{c}-.399 * * * \\
(.122)\end{array}$ & $\begin{array}{c}-.423^{* * *} \\
(.122)\end{array}$ & $\begin{array}{c}4.18^{* * *} \\
(.800)\end{array}$ & $\begin{array}{c}3.54 * * * \\
(.756)\end{array}$ & $\begin{array}{c}3.23 * * * \\
(1.05)\end{array}$ & $\begin{array}{c}3.47 * * * \\
(.766)\end{array}$ & $\begin{array}{c}3.49 * * * \\
(.764)\end{array}$ \\
\hline $\begin{array}{l}\text { Techno. } \\
\text { application } \\
\text { diversity }\end{array}$ & & $\begin{array}{c}.074 \\
(.050)\end{array}$ & & $\begin{array}{c}.050 \\
(.035)\end{array}$ & & $\begin{array}{c}-.504^{* *} \\
(.198)\end{array}$ & $\begin{array}{c}-.500^{* *} \\
(.205)\end{array}$ & $\begin{array}{l}-.445^{*} \\
(.205)\end{array}$ & $\begin{array}{l}-.433^{*} \\
(.204)\end{array}$ \\
\hline $\begin{array}{l}\text { Exploitation } \\
\text { alliance }\end{array}$ & & $\begin{array}{c}.271 * * * \\
(.082)\end{array}$ & & $\begin{array}{l}.174 * * \\
(.068) \\
\end{array}$ & & $\begin{array}{c}-1.07 * * \\
(.411) \\
\end{array}$ & $\begin{array}{c}-1.20 * * \\
(.425)\end{array}$ & $\begin{array}{c}-1.07 * * \\
(.415) \\
\end{array}$ & $\begin{array}{c}-1.05^{* *} \\
(.414) \\
\end{array}$ \\
\hline Article_t-1 & & & & & & & $\begin{array}{l}.270^{*} \\
(.119) \\
\end{array}$ & & \\
\hline Patent_t-1 & & & & & & & $\begin{array}{c}-858^{* *} \\
(.295)\end{array}$ & & \\
\hline $\begin{array}{l}\text { Research } \\
\text { orientation }\end{array}$ & & & & & & & & $\begin{array}{l}-.694^{*} \\
(.364)\end{array}$ & \\
\hline $\begin{array}{l}\text { Service } \\
\text { orientation }\end{array}$ & & & & & & & & & $\begin{array}{l}.749 * \\
(.353)\end{array}$ \\
\hline Spells & 1624 & 1624 & 1624 & 1624 & 1524 & 1524 & 1244 & 1507 & 1507 \\
\hline Groups & 313 & 313 & 313 & 313 & 300 & 300 & 275 & 298 & 298 \\
\hline Wald $\chi^{2}$ & $99.20^{* * *}$ & $116.77^{* * * *}$ & $97.23^{* * *}$ & $104.96^{* * *}$ & $260.87 * * *$ & $261.69 * * *$ & $326.76^{* * *}$ & $258.15^{* * *}$ & $260.61 * * *$ \\
\hline
\end{tabular}

$+p<.10 ; * p<.05 ; * * p<.01 ; * * * p<.001$. 
Table 3. Subgroup effects

\begin{tabular}{|c|c|c|c|c|c|c|}
\hline & Model 10 & Model 11 & Model 12 & Model 13 & Model 14 & Model 15 \\
\hline & \multicolumn{3}{|c|}{ Research Orientation } & \multicolumn{3}{|c|}{ Service Orientation } \\
\hline & \multicolumn{2}{|c|}{$\begin{array}{c}\text { Rent } \\
\text { generation }\end{array}$} & $\begin{array}{c}\text { Rent } \\
\text { appropriation }\end{array}$ & \multicolumn{2}{|c|}{$\begin{array}{c}\text { Rent } \\
\text { generation }\end{array}$} & $\begin{array}{c}\text { Rent } \\
\text { appropriation }\end{array}$ \\
\hline Dep. Variable & Article & Patent & Performance & Article & Patent & Performance \\
\hline Constant & $\begin{array}{l}-.260 \\
(.331)\end{array}$ & $\begin{array}{c}1.04 * * * \\
(.295)\end{array}$ & $\begin{array}{c}.225 \\
(.178)\end{array}$ & $\begin{array}{l}-.477 \\
(.317)\end{array}$ & $\begin{array}{c}1.10^{* * *} \\
(.154)\end{array}$ & $\begin{array}{l}-3.04 * \\
(1.49)\end{array}$ \\
\hline Prior_Perf & $\begin{array}{l}-.014 * * \\
(.005)\end{array}$ & $\begin{array}{l}-.015^{*} \\
(.007)\end{array}$ & $\begin{array}{l}.538^{* * *} \\
(.038)\end{array}$ & $\begin{array}{l}-.007 \\
(.009)\end{array}$ & $\begin{array}{l}-.005 \\
(.007)\end{array}$ & $\begin{array}{l}.080^{+} \\
(.049)\end{array}$ \\
\hline Debt-equity & $\begin{array}{l}-.0005^{*} \\
(.0002)\end{array}$ & $\begin{array}{l}-.0002 \\
(.0002)\end{array}$ & $\begin{array}{l}-.001 \\
(.001)\end{array}$ & $\begin{array}{l}-.000 \\
(.000)\end{array}$ & $\begin{array}{l}-.0002^{*} \\
(.0000)\end{array}$ & $\begin{array}{c}-.0022^{* * *} \\
(.0006)\end{array}$ \\
\hline Size & $\begin{array}{c}.047 \\
(.043)\end{array}$ & $\begin{array}{c}.144 * * * \\
(.039)\end{array}$ & $\begin{array}{l}.092 \\
(.200)\end{array}$ & $\begin{array}{l}.095^{*} \\
(.042)\end{array}$ & $\begin{array}{c}.069^{* * *} \\
(.018)\end{array}$ & $\begin{array}{l}-.047 \\
(.179)\end{array}$ \\
\hline Public & $\begin{array}{c}.044 \\
(.120)\end{array}$ & $\begin{array}{c}.122 \\
(.118)\end{array}$ & $\begin{array}{l}-.334 \\
(.625)\end{array}$ & $\begin{array}{c}.082 \\
(.145)\end{array}$ & $\begin{array}{c}.013 \\
(.069)\end{array}$ & $\begin{array}{l}.160 \\
(.614)\end{array}$ \\
\hline Governance & $\begin{array}{c}.081 \\
(.096)\end{array}$ & $\begin{array}{c}.003 \\
(.092)\end{array}$ & $\begin{array}{l}-.102 \\
(.492)\end{array}$ & $\begin{array}{c}.013 \\
(.105)\end{array}$ & $\begin{array}{l}.120^{* *} \\
(.051)\end{array}$ & $\begin{array}{l}-.412 \\
(.460)\end{array}$ \\
\hline Subsidiary & $\begin{array}{l}-.015 \\
.213)\end{array}$ & $\begin{array}{c}.036 \\
(.190)\end{array}$ & $\begin{array}{l}1.25 \\
(.913)\end{array}$ & $\begin{array}{l}-.154 \\
(.211)\end{array}$ & $\begin{array}{l}.196^{*} \\
.091)\end{array}$ & $\begin{array}{c}.652 \\
(.885)\end{array}$ \\
\hline Independent & $\begin{array}{l}-.046 \\
(.188)\end{array}$ & $\begin{array}{l}.397 * \\
(.164)\end{array}$ & $\begin{array}{l}.407 \\
(.803)\end{array}$ & $\begin{array}{c}.102 \\
(.170)\end{array}$ & $\begin{array}{c}.104 \\
(.073)\end{array}$ & $\begin{array}{c}.123 \\
(.718)\end{array}$ \\
\hline Density & $\begin{array}{l}.116^{+} \\
(.073)\end{array}$ & $\begin{array}{l}-.022 \\
(.071)\end{array}$ & $\begin{array}{l}-.868^{*} \\
(.399)\end{array}$ & $\begin{array}{l}.104 \\
(.070)\end{array}$ & $\begin{array}{l}.023 \\
(.041)\end{array}$ & $\begin{array}{l}-.208 \\
(.291)\end{array}$ \\
\hline $\begin{array}{l}\text { International } \\
\text { exposure }\end{array}$ & $\begin{array}{l}.162^{+} \\
(.088)\end{array}$ & $\begin{array}{l}.347 * * * \\
(.090)\end{array}$ & $\begin{array}{l}-1.52^{* *} \\
(.539)\end{array}$ & $\begin{array}{l}.322^{* * *} \\
(.101)\end{array}$ & $\begin{array}{l}.234^{* * *} * \\
(.064)\end{array}$ & $\begin{array}{l}-.580 \\
(.497)\end{array}$ \\
\hline Experience & $\begin{array}{l}.423^{* * * *} \\
(.124)\end{array}$ & $\begin{array}{c}-.280^{* *} \\
(.114)\end{array}$ & $\begin{array}{l}1.44^{+} \\
(.870)\end{array}$ & $\begin{array}{l}.396^{* *} \\
(.143)\end{array}$ & $\begin{array}{c}-.296 * * * \\
(.071)\end{array}$ & $\begin{array}{l}1.61^{+} \\
(.760)\end{array}$ \\
\hline Censure-left & $\begin{array}{l}.759^{* * *} \\
(.218)\end{array}$ & $\begin{array}{l}-.422^{*} \\
(.209)\end{array}$ & $\begin{array}{l}3.07^{*} \\
(1.59)\end{array}$ & $\begin{array}{l}.749 * * * \\
(.243)\end{array}$ & $\begin{array}{c}-.475^{* * * *} \\
(.120)\end{array}$ & $\begin{array}{c}4.24 * * * \\
(1.34)\end{array}$ \\
\hline $\begin{array}{l}\text { Techno. } \\
\text { application } \\
\text { diversity }\end{array}$ & $\begin{array}{l}-.007 \\
(.079)\end{array}$ & $\begin{array}{c}.002 \\
(.070)\end{array}$ & $\begin{array}{l}-.745^{*} \\
(.333)\end{array}$ & $\begin{array}{l}.158^{*} \\
(.068)\end{array}$ & $\begin{array}{l}.047+ \\
(.028)\end{array}$ & $\begin{array}{l}-.094 \\
(.281)\end{array}$ \\
\hline $\begin{array}{l}\text { Exploitation } \\
\text { alliance }\end{array}$ & $\begin{array}{l}.281 * * \\
(.113)\end{array}$ & $\begin{array}{l}.258^{*} \\
(.116)\end{array}$ & $\begin{array}{l}-.790 \\
(.621)\end{array}$ & $\begin{array}{l}.227^{+} \\
(.130)\end{array}$ & $\begin{array}{c}.081 \\
(.064)\end{array}$ & $\begin{array}{l}-1.10^{*} \\
(.571)\end{array}$ \\
\hline Article_t-1 & & & $\begin{array}{l}.302^{+} \\
(.174)\end{array}$ & & & $\begin{array}{c}.010 \\
(.173)\end{array}$ \\
\hline Patent_t-1 & & & $\begin{array}{c}-.974 * \\
(407)\end{array}$ & & & $\begin{array}{l}-.216 \\
(430)\end{array}$ \\
\hline Spells & 846 & 846 & 642 & 753 & 753 & 587 \\
\hline Groups & 159 & 159 & 140 & 149 & 149 & 133 \\
\hline Wald $\chi^{2}$ & $66.77 * * *$ & $62.23 * * *$ & $304.78^{* * *}$ & $65.18^{* * *}$ & $71.87 * * *$ & $38.98^{* * *}$ \\
\hline
\end{tabular}

$+p<.10 ; * p<.05 ; * * p<.01 ; * * * p<.001$ 


\section{References}

Afuah A. 2000. How much do your co-opetitors' capabilities matter in the face of technological change? Strategic Management Journal 21(3): 397-404

Allansdottir A, Bonaccorsi A, Gambardella A, Mariani M, Orsenigo L, Pammolli F, Riccaboni M. 2002. Innovation and Competitivness in European Biotechnology. European Commision Enterprise Directorate General: Brussels

Almeida P, Kogut B. 1999. Localization of knowledge and the mobility of engineers in regional networks. Management Science 45(7): 905-918

Alvarez SA, Barney JB. 2001. How entrepreneurial firms can benefit from alliances with large partners. Academy of Management Executive 15(1): 139-148

Alvarez SA, Barney JB. 2004. Organizing rent generation and appropriation: toward a theory of the entrepreneurial firm. Journal of Business Venturing 19: 621-635

Arundel A. 2001. The relative effectiveness of patents and secrecy for appropriation. Research Policy 30(4): 611-624

Bae J, Gargiulo, M. 2004. Partner substitutability, alliance network structure, and firm profitability in telecommunications industry. Academy of Management Journal 47: 860-875

Barney J. 1991. Firm Resources and Sustained Competitive Advantage. Journal of Management 17(1): 99-120

Baum JAC, Calabrese T, Silverman BS. 2000. Don't go it alone: alliance network composition and startups' performance in Canadian biotechnology. Strategic Management Journal 21: 267-294

Baum JAC, Silverman, B.S. 2004. Picking winners or building them? Alliance, intellectual, and human capital as selection criteria in venture financing and performance of biotechnology startups. Journal of Business Venturing 19(3): 411-436

Carroll G-R. 1985. Concentration and specialization: Dynamics of niche width in populations of organizations. The American Journal of Sociology 90(6): 1262-1283

Coff R. 1999. When competitive advantage doesn't lead to performance: Resource-based theory and stakeholder bargaining power. Organization Science 10(2): 119-133

Coff R, Lee P. 2003. Insider trading as a vehicle to appropriate rent from R\&D. Strategic Management Journal 24(2): 183-190

Deberdt D. 2005. The cost of a European patent, Actuality Proceedings. INPI: Paris

Deeds DL, Hill CWL. 1996. Strategic alliances and the rate of new product development: An empirical study of entrepreneurial biotechnology firms. Journal of Business Venturing 11(1): 41-55

Dhanarag C, Parkhe A. 2006. Orchestrating innovation networks. Academy of Management Review 31(3): 659-669

Durand R, Coeurderoy R. 2001. Age, order of entry, strategic orientation, and organizational performance. Journal of Business Venturing 16(5): 471-494 
Ernst\&Young. 1999. Bridging the Gap. Ernst Young International

Ernst\&Young. 2001. Life Sciences in France - 2001. Where creativity meets business. Ernst Young International: Paris

Franklin JJ, Johnston R. 1988. Co-citation bibliometrics as a tool of S\&T and R\&D management: Issues, applications, and developments. In A Van Raan (Ed.), The Handbook of Quantitative Studies of Science and Technologies: 325-389. North-Holland: Amsterdam

Gittelman M, Kogut B. 2003. Does good science lead to valuable knowledge? Biotechnology firms and the evolutionary logic of citation patterns. Management Science 49(4): 366-382

Greene WH. 2005. Econometric Analysis. Prentice-Hall

Gulati R, Higgins MC. 2003. Which ties matter when? The contingent effects of interorganizational partnerships on IPO success. Strategic Management Journal 24: 127-144

Gulati R, Nohria N, Zaheer A. 2000. Strategic networks. Strategic Management Journal 21(3): 203-215

Healy P, Rothman H, Hock PK. 1986. An experiment in science mapping for research planning. Research Policy 15(5): 233-252

Hunter JE, Schmidt FL. 1990. Methods of Meta-Analysis: Connecting Error and Bias in Research Findings. Sage: Newbury Park, CA

Lane HW, Lubatkin M. 1998. Relative absorptive capacity and interorganizational learning. Strategic Management Journal 19(5): 461-477

Lavie D. 2006. The competitive advantage of interconnected firms: an extension of the resourcebased view. Academy of Management Review 31(3): 638-658

Lerner J. 1994. The importance of patent scope: an empirical analysis. Rand Journal of Economics 25(2): 319-333

Levinthal D. 1997. Adaptation on rugged landscapes. Management Science 43(7): 934-950 95-112

Levinthal DA, March JG. 1993. The myopia of learning. Strategic Management Journal 14(S2):

Mangematin V, Lemarie S, Boissin JP, Catherine D, Corolleur F, Coronini R, Trommetter M. 2003. Development of SMEs and heterogeneity of trajectories: the case of biotechnology in France. Research Policy 32(4): 621-638

McNamara P, Baden-Fuller C. 2007. Shareholder returns and the exploration-exploitation dilemma: R\&D announcements by biotechnology firms. Research Policy 36(4): 548-565

Meyer-Krahmer F, Schmoch U. 1998. Science-based technologies: university-industry interactions in four fields. Research Policy 27(8): 835-851

Moran P, Goshal S. 1999. Markets, firms, and the process of economic development. Academy of Management Review 24(3): 390-412 
Morrow JL, Sirmon, D.G., Hitt, M.A., and Holcomb, T.R. 2007. Creating value in the face of declining performance: firm strategies and organizational recovery. Strategic Management Journal 28: 271-283

Nesta L, Saviotti P. 2005. Coherence of the knowledge base and the firm's innovative performance. Evidence from the US bio-pharmaceutical industry. The Journal of Industrial Economics LIII(1): 105-125

Niosi J. 2003. Alliances are not enough explaining rapid growth in biotechnology firms. Research Policy 32(5): 737-750

O'Reilly III CA, Tushman ML. 2004. The Ambidextrous Organization. Harvard Business Review April: 74-81

Owen-Smith J, Powell WW. 2001. To patent or not: Faculty decisions and institutional success at technology transfer. The Journal of Technology Transfer 26(1-2): 99-114

Penrose ET. 1959. The Theory of the Growth of the Firm. Wiley: New York

Peteraf M. 1993. The cornerstones of competitive advantage: A resource-based view. Strategic Management Journal 14: 179-191

Powell WW, Koput KK, Smith-Doerr L. 1996. Interorganizational collaboration and the locus of innovation: networks of learning in biotechnology. Administrative Science Quarterly 41(1): 116-145

Powell WW, White DR, Koput KW, Owen-Smith J. 2005. Network Dynamics and Field Evolution: The Growth of Interorganizational Collaboration in the Life Sciences. American Journal of Sociology 110(4): 1132-1205

Reiss T, Hinze S, Domingues-Lacasa I. 2004. Performance of European Member States in biotechnology. Science and Public Policy 15: 344-358

Rosenkopf L, Nerkar A. 2001. Beyond local search: Boundary-spanning, exploration, and impact in the optical disk industry. Strategic Management Journal 22(4): 287-306

Rothaermel FT. 2001. Incumbent's advantage through exploiting complementary assets via interfirm cooperation. Strategic Management Journal 22(6-7): 687-699

Rothaermel FT, Deeds DL. 2004. Exploration and exploitation alliances in biotechnology: A system of new product development. Strategic Management Journal 25(3): 201-221

Rothaermel FT, Deeds DL. 2006. Alliance type, alliance experience and alliance management capability in high-technology ventures. Journal of Business Venturing 21(4): 429-460.

Sampson RC. 2007. R\&D Alliances and Firm Performance: The Impact of Technological Diversity and Alliance Organization on Innovation. Academy of Management Journal 50(2): 364-386

Sarkar MB, Echambadi R, Harrison JS. 2001. Alliance entrepreneurship and firm market performance. Strategic Management Journal 22(6-7): 701-711

Shan W, Walker G, Kogut B. 1994. Interfirm cooperation and startup innovation in the biotechnology industry. Strategic Management Journal 15(5): 387-394 
Shane S. 2001. Technology regimes and new firm formation. Management Science 47(9): 11731190

Sirmon DG, Hitt MA, Ireland RD. 2007. Managing firm resources in dynamic environments to create value: Looking inside the black box. Academy of Management Review 32(1): 273-292

Soh PH, Mahmood OP, Mitchell W. 2004. Dynamic inducements in R\&D investment: Market signals and network locations. Academy of Management Journal 47(6): 907-917

Somaya D. 2003. Strategic determinants of decisions not to settle patent litigation. Strategic Management Journal 24(1): 17-38

Stuart TE. 2000. Interorganisational alliances and the performance of firms: A study of growth and innovation rates in a high-technology industry. Strategic Management Journal 21: 791-811

Stuart TE, Hoang H, Hybels RC. 1999. Interorganizational endorrsements and the performance of entrepreneurial ventures. Administrative Science Quarterly 44(2): 315-349

Stuart TE, Ozdemir SZ, Ding WW. 2007. Vertical alliance networks: The case of universitybiotechnology-pharmaceutical alliance chains. Research Policy 36(4): 477-498

Teece DJ, Pisano G, Shuen A. 1997. Dynamic capabilities and strategic management. Strategic Management Journal 18(7): 509-533

Tijssen R. 2004. Is the commericalization of scientific research affecting the production of public knowledge? Global trends in the output of corporate research articles. Research Policy 33(5): 709-733

van Beuzekom B, Arundel A. 2006. OECD Biotechnology Statistics. OECD: Paris

Williamson OE. 1985. The Economic Institutions of Capitalism. Free Press: New York

Winter S. 1995. Four Rs of probability: rents, resources, routines and replication. In CA Montgomery (Ed.), Resource-Based and Evolutionary Theories of the Firm: Towards a Synthesis: 147-178. Kluwer Academic Publishers: Boston/Dordrecht/London

Zucker LG, Darby MR, Armstrong JS. 2002. Commercializing knowledge: University science, knowledge capture, and firm performance in biotechnology. Management Science 48(1): 138-153

Zucker LG, Darby MR, Brewer B. 1998. Intellectual human capital and the birth of the US biotechnology enterprise. American Economic Review 88(1): 290-306 